\title{
Corporate Governance and Protection of Stakeholders Rights and Interests
}

\author{
Kingsley 0. Mrabure1, Alfred Abhulimhen-Iyoha² \\ ${ }^{1}$ Faculty of Law, Delta State University, Abraka, Nigeria \\ ${ }^{2}$ Chief Magistrate Grade 1, Edo State Judiciary, High Court Complex, Benin-City, Nigeria \\ Email:kingomote@yahoo.com, aaiyoha@yahoo.com
}

How to cite this paper: Mrabure, K. O., \& Abhulimhen-Iyoha, A. (2020). Corporate Governance and Protection of Stakeholders Rights and Interests. Beijing Law Review, 11, 292-308.

https://doi.org/10.4236/blr.2020.111020

Received: February 10, 2020

Accepted: March 22, 2020

Published: March 25, 2020

Copyright $\odot 2020$ by author(s) and Scientific Research Publishing Inc. This work is licensed under the Creative Commons Attribution International License (CC BY 4.0).

http://creativecommons.org/licenses/by/4.0/ (c) (i) Open Access

\begin{abstract}
The paper takes a holistic view of corporate governance (CG) and protection of stakeholders' rights and interests. It analyzes whether effective boards of directors in addressing shareholders' interests prove to be effective in guaranteeing the interests of the rest of the firm's stakeholders. It discusses how corporate governance should be shaped in relation to existing firms, according in particular to some subjective criteria of fairness and fair play. It defines CG and explains the concept by stating its principles and codes as contained in the Organization for Economic Cooperation and Development (OECD). It states that countries such as Nigeria, the United States and the United Kingdom have developed their CG principles with corporate social responsibility (CSR) intent by using as a guideline the OECD principles and other sources of rules and principles of CG which includes the Companies and Allied Matters Act, Investment and Securities Act and a host of others. It states that the concept of CG applies to corporate businesses across the globe by highlighting the importance and specifying the distribution of rights and responsibilities among various corporate stakeholders such as board members, managers, shareholders and outlining the rules and procedures for making decisions. In doing so, it also provides the mechanism by which the company's objectives are set, ways to achieve these and monitoring performance. The paper acknowledges that CG is a vital issue where a corporate organization is concerned but asserts that it is impossible for an organization to satisfy all stakeholders hence it is best to create a balance between meeting organizational objectives and that of its stakeholders.
\end{abstract}

\section{Keywords}

Corporate Governance (CG), Stakeholders, Directors, Shareholders, Protection 


\section{Introduction}

The stakeholder principle has gained increased recognition in corporate governance (CG) in the recent times since the commencement of the separation of ownership and control in corporations, the shareholder model of corporate governance increasingly became associated with agency theory. This theory holds that managers are the agents of shareholders (or owners) and in their capacity as agents, are obligated to act in the best financial interest of the shareholders of the corporation (Monks \& Minow 2004). It is the refinement of a more narrow definition of companies as vehicles whose purpose is to promote their shareholders' economic interests.

The stakeholders' idea was always present in corporate legislations. The proof of this fact is the creditor protection scheme which is one of the fundamental principles. The stakeholders' vision articulated in the recent times is however more expansive and proactive. This covers a whole host of non-shareholders' groups-employees, suppliers and so on-and seeks to promote active corporate engagement in protecting the interests of these groups and promoting their welfare.

In view of the above, this paper seeks to examine CG with corporate social responsibility (CSR) intent and protection of stakeholders in corporate organizations by highlighting the importance and specifying distribution of rights and responsibilities among various members of the corporation, such as board members, managers, shareholders and other stakeholders and outlining rules and procedures for making decisions. It also aims at examining the structure by which the company's objectives are set, ways of doing these and monitoring performance.

\section{Definition of Corporate Governance}

There is no single definition of CG, rather it could be viewed from various angles. CG is the structure which directs and regulates business corporations. The structure of the CG specifies the distribution of rights and responsibilities among various corporate participants such as the board, managers, shareholders and other stakeholders, and outlines the rules and procedures for making decisions on corporate matters. In doing so, it also provides the structure through which the firm operates, objectives are set, ways of achieving and monitoring those objectives and performance (Organisation for Economic Co-operation and Development OECD, 1999).

Wieland's defines corporate governance "as leadership, management and control of a firm by formal and informal, public and private rules" (Wieland 2005). Berle and Means define corporate governance as 'allocation of ownership, capital structure, managerial incentive schemes, takeovers, board of directors, institutional investors' pressure, product market competition, labour market competition, organizational structure, etcetera., all can be considered as institutions affecting the process through which quasi rent is distributed' (Berle \& 
Means 1932). Oman described corporate governance as a term refers to public and private institutions which include laws, regulations and business practices governing the relationship between corporate managers and stakeholders (Oman 2001). La Porta, Silanes and Shliefer view corporate governance as a set of mechanisms through which outside investors (shareholders) protect themselves from inside investors' managers (La Porta, Lopez-De-Silanes, \& Shleifer 2000).

On his part, Imala states that corporate governance is the system of internal controls and procedures by which individual companies are managed. It provides a framework that specifies the rights, roles and responsibilities of different groups, management, the board and shareholders within an organization (Imala, 2007). Collier and Roberts state that when the corporation is conceived of as a social institution, the purpose of corporate governance is "aligning and balancing a wide variety of potentially competitive interests within the corporation" (Collier \& Roberts 2001).

Oladimeji citing McRitchie viewed corporate governance as principle that focus on transparency, accountability, boards disclosure, investors involvement and related issues. He added that firms with stronger shareholder rights would have higher firm value, higher profits, higher sale growth, lower capital expenditure and few corporate acquisition. Effectively, corporate governance reduces control right (Oladimeji 2007, McRitchie, 2001).

On this level corporate governance refers to both the legal and regulatory environment within which corporations function, as well as to the market for corporate control. The former consists of the control over companies through institutions like the state, the judiciary and stock exchanges. They exercise external control over companies in general and over securities transactions in particular by determining the network of laws, rules and regulations within which corporations have to operate (Coffee 1998, Romano 1998).

Therefore, CG deals with how to make those in corporate management more accountable, more responsible and more sensitive to the interest of shareholders, creditors, members of the public and social interests respectively. CG as a concept can be viewed merely as being concerned with the structures within which a corporate entity or enterprise receives its basic orientation and direction.

\section{Literature Review}

Emmon and Schmid citing Shleifer and Vishny they postulated that corporate governance ensured investors in corporation received adequate return on their investment otherwise, outside investors would not lend to the firm or purchase their equity securities. Consequently, firm would be forced to rely on internally generated funds. They added that legal and political environment are critical influence on the nature of corporate governance and there by improve corporate performance in every country (Emmons \& Schmid 1999, Shleifer \& Vishny 1997). Hence investor protection and stronger rule of law are related to corpo- 
rate governance and organization performance.

Mehar examined corporate governance and dividend policy. He noted that payment of dividend is extremely important and in some economies firms are even forced to pay dividend through external finance (Mehar 2003). Abdullah and Valentine postulated that the fundamental theories of corporate governance started with the discussion of agency theory expended to stewardship theory, stakeholder theory and evolved to resource dependency, transaction cost, political and ethical related theories like business and virtue ethics. However, these theories address the cause and effect of variable such as the configuration of board members, audit committee, independent director and top management and their social relationships rather than it regulatory framework. They concluded that combination of various theories would be the best approach to described good governance practice rather than focusing on single theory (Abdullah \& Valentine 2009).

Similarly, Kajola examined the nexus between corporate governance mechanisms and firm performance using panel method and ordinary least square as a method of estimation, his findings revealed evidence of positive significant relationship between corporate governance mechanism and measure of organization performance (Kajola 2008). Odaki and Kodama argued that the theories of economic institutions predict that complimentary exists between the natures of corporate governance of its human capital investment. They postulated that the way a firm is owned and controlled is interrelated with human capital investment and the way employees are trained and paid (Odaki \& Kodama 2010).

\section{Principles of Corporate Governance}

The principle of CG was first highlighted in Cadbury Report (United Kingdom, 1992). In Nigeria, the Organization for Economic Cooperation and Development (OECD) Principles of Corporate Governance gave the general principle of good governance to companies. Among the principle are the following: board members should be informed and act ethically and in good faith, with due diligence and care in best interest of the company and shareholders, review and guide corporate strategy, objective setting, major plans of action, risk policy, capital plans and annual budgets, oversee major acquisitions and diversifications, select, compensate, monitor and replace key executives and oversee succession planning, ensure a formal and transparent board member nomination and election process and where committees of the board are established, their mandate, composition and working procedures should be well-defined and disclosed (OECD 1998, 2004).

CG principles and codes have been developed in many countries using as a guideline the OECD principles. The United States adopted several principles of the OECD as seen in Sarbenes-Oxley Act thus: rights and equitable treatment of shareholders, role and responsibilities of the board, integrity and ethical behaviour, disclosure and transparency and interest in other stakeholders (such as 
creditors, employees, suppliers, local communities, customers and government) (United States 2002).

In United Kingdom, the code of CG has been severally updated and the latest being the code of corporate governance of 2010 which reinforced the UK Stewardship Code 2010. Some of the key aspects of CG in the code includes: a single board collectively responsible for sustainable success of the company, good checks and balances, effective rights for shareholders who are encouraged to engage with the companies in which they invest, a balance of executive and independent non-executive directors, strong, independent audit and remuneration committees and transparency on appointments and remuneration.

In Nigeria, aside the international code of CG, other sources of rules and principles of CG includes: The Companies and Allied Matters Act of 2004, Investment and Securities Act of 2007, Securities and Exchange Commission Rules (2013), Bank and Other Financial Institutions Act of 2004, Insurance Act of 2004, Code of Corporate Governance for Banks in Nigeria Post Consolidation, Code of Corporate Governance for Public Companies in Nigeria, Code of Corporate Governance for Insurance Industry in Nigeria and Code of Conduct for Capital Market Operators and their Employees.

The Companies and Allied Matters Act (CAMA) is the major law regulating CG in Nigeria. It provides mechanisms for good CG among which are appointment of directors by the company, removal of directors by ordinary resolution, duties and liabilities of the directors, provisions for auditors and audit committee, disclosure provisions, mandatory involvement of shareholders in some corporate decisions etcetera.

The concept of CG applies to corporate businesses across the globe and there are certain principles that have become accepted as well as required to be followed: These are:

1) Rights and Equitable Treatment of Shareholders: This means the organization is bound to respect and uphold the fundamental rights of its shareholders as well as give freedom for the expression of their rights. Also, the right to participate in the affairs of the corporation should be clearly and properly interpreted.

2) Interest of Stakeholders: This involves the organization clearly stating its legitimate stakeholders in its policies and incorporating them into its operations recognizing their legal, moral, and social obligations which should be fulfilled.

3) Role and responsibility of the board of directors: Board members should be persons with the required knowledge with vast experience in handling over management challenges. The size of the board should be determined by the required scope of responsibilities and duties.

4) Integrity and ethical behaviour: This means being a responsible company guiding the actions of directors and executives through a code of conduct established to ensure ethical and responsible decision-making.

5) Disclosure and transparency: Shareholders' information about the organization should be clearly and truthfully informed by the board and management. 
Mechanisms and procedures should be put in place to ensure that the organisation's integrity is maintained. These measures include the involvement of independent auditors, members of the board to check unethical behaviour or actions within the organization (Oso, Semiu 2012).

\section{Inside and Outside Stakeholders}

There exist various groups of individuals that play important roles as well as have an impact on CG. These individual groups are referred to in the organization as internal and external. stakeholders. Those internal groups of people by authority level include: Shareholders who are the owners of a company whose main concern is that their investment in the company yields benefits and maximum returns the board of directors who are shareholder representatives appointed to pilot the affairs of the organization, management and these are those responsible for the day-to-day operations of the organization (Wogu 2019).

The external groups of individuals include: Employees who are individuals that make up the labour force of an organization. These are the manpower tools that a company aims to achieve its goals and objectives and customers who are the categories of persons representing the raison d'être of the business. They are the ones whose needs the business profitably meet, creditors who provide finance which the organization utilizes for growth and expansion, suppliers who make available various inputs required by the organization to ensure its smooth running, Investors who are individuals or group of individuals having capacity to invest resources in an organization. These resources could be financial, technical, manpower etcetera, Government regulatory authorities which comprise of group of individuals with delegated authority from government to formulate laws and codes and also to monitor and control activities of business organizations and Host community which refers to the people and area where the corporation is situated that is the geographical location of the organization.

OECD Principles of CG asserts that the CG framework should recognize stakeholders' rights established by law or through mutual agreements and encourage active cooperation between corporations and stakeholders in creating wealth, jobs, and the sustainability of financially sound enterprises (OECD 2004).

A company is accountable to its shareholders and to its stakeholders with whom it deals, as well. They asserts that due to limited resources, companies must identify their primary stakeholders and therefore create a governance system that incorporates the needs and interests of stakeholders and corporate interests (Ferrell, Fraedrich, \& Ferrell 2005). The organization can prioritize its stakeholders in order to determine the strategic choices in managing those relationships. This can be accomplished by recognizing and categorizing stakeholders according to their level of power and legitimacy on the organization. Kazmi attest that the importance of the stakeholders to the organization can be determined by the impact on the organization of the strength and nature of support or opposition that the specific stakeholder has (Kazmi 2008). 


\section{Role of Stakeholders in Corporate Governance}

Donaldson and Preston identify stakeholders as any group that has an interest in the corporation regardless of whether the firm has any corresponding functional interest in them. Accordingly, the stakeholder-centered view of the firm has been defined as the belief that "each group of stakeholders merits consideration for its own sake and not merely because of its ability to further the interests of some other group, such as shareowners" (Donaldson \& Preston 1995).

While Freeman suggests that any "group or individual who can affect or is affected by the achievement of the organization's objectives" can be called a stakeholder, theorists often try to narrow their attention towards the most important sets of actors for a given context (Freeman, 1994). Carroll limits his definition of stakeholder to those actors who possess either a legal or a moral claim over the actions of the firm (Carroll, 1979). Blair, Aguilera and Jackson further argue that only stakeholders with a significant firm specific investment should enjoy influence in discussions about corporate control (Blair, 1995, Aguilera \& Jackson 2003).

Though external to an organization stakeholders cannot be dismissed as irrelevant due to the different roles they play and their effect on the organization's activities. It is opined that CG deals with the mechanisms by which corporate stakeholders exercise control of corporate insiders and management to ensure their interests are protected (John \& Senbet 1998). It is therefore it is important that organizations are familiar with stakeholder rights as laid down by law. The organization should also cooperate actively with its stakeholders in creating wealth, jobs and a financially sound enterprise.

Having established the importance of stakeholders to the corporation, it becomes necessary to portray the role they play in ensuring CG. It has been suggested that stakeholders' approach to CG helps to provide answers to the important issue of priorities in relationships among stakeholders as well as how to manage these relationships (Freeman 2008). Stakeholders are characterized by their relationship with the company as well as interest, needs and concerns that arise, thus becoming the focusing point of the engagement process with the organization (Zollinger, 2009). The author further posits that these roles include but are by no means limited to the following:

Experts that knowledgeable experts in diverse fields of endeavour are useful in offering strategic advice to the company's board when invited, Technical Advisers are individuals who possess expertise in technological and scientific developments can offer well informed advice on scientific and ethical panels on the social and environmental risks associated with such developments especially in science-related industries, representatives of special interests: the review of company performance and of reporting practices can be carried out by its employees, local communities etcetera as they meet as stakeholders panel upon invitation, Co-implementers as this situation arises when an external body for instance a Non-Governmental Organization (NGO) partner with the company to 
jointly provide solution to an issue or address a shared challenge and co-monitor as this situation arises when the impacted communities having entered an agreement with the company become jointly responsible for the monitoring of the company's sustainability projects (Ibid).

\section{Stakeholder Principles}

Traditionally in the common-law countries, shareholders are understood to be the owners of companies (Berle \& Means 1932). This is seen under the UK. Company law in which the statutes classify shareholders as "members" and describe companies as shareholders pursuant to Articles 16, 112 and 113 of the Company Act 2006. Indeed, they refer regularly to the shareholders' body as the firm. This reflects the underlying notion of identity between the shareholders and the companies. Shareholders have the right to elect and remove directors who control the corporations.

\section{Minority Shareholders as Stakeholders}

Minority and dispersed shareholders could be perceived as a kind of stakeholders, rather than owners outright, whose interests are impacted by the decisions of controlling shareholders and top management. Indeed, as remarked above, part of the legal provisions affecting CG such as those concerning the publicity and fidelity of accounts are aimed in particular at protecting non-controlling shareholders (as well as creditors). More generally, the law provides guarantees for the co-owners each towards the others and so its constraints may not be adverse, but rather favourable, to the forming of agreements establishing a company, as they may discipline and prevent ex-post opportunistic behaviour, whilst also protecting other types of stakeholders such as creditors, or the Inland Revenue and taxpayers. Contestability of corporate control is seen for well-known reasons, as a guarantee for non-controlling shareholders, as well as an instrument leading to a better allocation of productive resources. As well known, the rules for enabling the non-controlling shareholders to benefit of the potential profitability of the firm by selling their shares to a bidder in public tender offers are devised on the one hand to allow the totality of shareholders to be in the position to take advantage of the bid and thus of the premium of control and on the other to render the bids more onerous, avoiding an excessive instability in corporate administration and a tendency towards excessive short-termism (such as having managers to be all too dependent on the continuously changing moods of the stock exchange instead of planning for the long term), but it may throw in prohibitive obstacles towards the challenging of consolidated positions. As often is the case, there are no clear-cut answers, only trade-offs.

\section{Concept of "Enlightened Shareholder Value" (ESVP)}

The UK's, Companies Act 2006, although still maintained the shareholder primacy tradition has enshrined in law the concept of "enlightened shareholder 
value" (ESVP), a form of corporate social responsibility, acclaimed by commentators as "a positive step forward towards the formation of more ethical companies and a more Europeanized corporate governance model, combining continental CG characteristics with the shareholder primacy model. Under this approach, emphasis is on the long-term interest of the company, which in turn means having considerable regards to the interest of stakeholders such as employees, creditors, suppliers, customers, the local communities and the environment as envisaged under section 172 of the Companies Act 2006. Additionally, in response to the 2008 financial crisis, various authorities in the UK now assert the importance of promoting stakeholders' interest for the long-term interest of the company; as the pursuit of immediate short-term interest and a lack of social responsibility to stakeholders have been suggested as the main reasons for the world financial crisis of 2008.

Similarly, in Nigeria, the Securities and Exchange Commission ("SEC"), the regulatory body for listed corporate bodies, aware that a weak CG structure has been responsible for some recent corporate failures in Nigeria, in 2008 reviewed the 2003 Code of Corporate Governance for Public Companies to address weaknesses and improve the mechanism for enforceability, thus giving it a stakeholder model approach. Although, the said code is applicable to only public companies in Nigeria, the SEC encourages other companies to use the principles set out in the code, where appropriate in the conduct of their affairs (SEC 2019).

Furthermore, the Central Bank of Nigeria (CBN) in May 2014, recognizing that "a country's economy depends on the safety and soundness of its financial institutions, issued new code of CG for Banks and Discount Houses in Nigeria", and Guidelines for Whistle Blowing in the Nigerian Banking Industry with corporate social responsibility (CSR) intent ((code of CG 2015). According to the CBN, the effectiveness with which the boards of financial institutions discharge their responsibilities determines the country's competitive position (Ibid).

Although, they are free to drive their institutions forward, such freedom must be exercised within a framework of transparency and effective accountability, that being the essence of any good system of CG. The said guidelines, makes the Board of directors accountable and responsible for the performance and affairs of the bank and in line with the provisions in the Nigeria's Companies and Allied Matters Act, directors owe the bank the duty of care and loyalty to act in the interest of the bank's employees and other stakeholders. Of significant importance is paragraph 4.1 .3 of the guidelines, which specifically encourages banks to show good sense of corporate social responsibility to its stakeholders such as clients, employees, host communities and the general public (Ibid).

It follows that, although the evolution of the CSR concept may have been chequered, it has in recent times been recognized as an important concept in CG. Corporations have been encouraged by CG rules and codes to carry out a stakeholder model approach in managing their affairs. To the effect that corporations now have built-in mechanisms for CSR. CSR and socially responsible in- 
vestment has today provided opportunities for companies to support their activities with broader societal expectations, making CSR as a concept to cover many more issues; encompassing sustainable development, CG development and corporate objectives, employment rights, consumer protection rights, health and safety at work, local taxation law and socially responsible investments from shareholders.

But again, should companies seek only to maximize shareholders' value or strive to serve the often conflicting interest of all stakeholders? Or in whose interest should companies be run? The next segment of the essay, will attempt to find answers to the questions by exploring the shareholder-stakeholder debate.

\section{Shareholder Primacy and CS}

A side to the discussion is the shareholder primacy theory, which is a dominant principle in the English corporate law (Davies \& Worthington 2012). Here, it is generally accepted that the main objective of companies is to maximize shareholders' wealth (Friedman 2002). Advocates of this theory believe that by providing a necessary product or service at a reasonable price, a business is benefiting society already (Gelter 2011). Therefore, spending shareholder money for Therefore, spending shareholder money for unprofitable social causes is unnecessary and unwise, because shareholders have made an investment and are dependent on the company to provide them with a return (Carroll 1979).

The Michigan Supreme Court's decision in the case of Dodge v Ford Motor Company in 1919, established the legal foundation of the shareholder primacy theory (Michigan 1919). The court stated: "a business corporation is organised and carried on primarily for the profit of the stockholders." It follows that the cardinal objective of this theory is to ensure that company directors manage corporations for the purpose of maximizing shareholders' wealth to the full extent, as they have only economic goals and responsibilities to shareholders (Friedman 2002). Therefore, the directors are sanctioned to do anything under the law which can increase shareholders wealth (Friedman 1962). The theory thus avoids yielding to the CSR which requires directors to consider the interests of other stakeholders when making decisions.

From the name, it can be inferred that shareholders are the only subject of this theory. It follows also that shareholders' interests will always take priority and other stakeholders' interests or benefits are very much ancillary to the interest of shareholders. This is however, not to say that companies' directors do not take the interest or benefits of other stakeholders into account when making decisions, unless considering their interest will undermine shareholders' wealth. After all, as advocates of this theory believe, unlike shareholders, other stakeholders' rights and interests are gained and protected through contracts with the company (Jensen 2002). But then again should companies seek only to maximize shareholder value or strive to serve the interest of all stakeholders? To address this question, we shall briefly explore some arguments for and against this theory. 


\subsection{Arguments against Shareholder Primacy Theory}

\section{1) Short-Term Perspective}

It has been argued that placing emphasis on shareholders' wealth encourages businesses to focus on short-term profit maximization to the neglect of other stakeholders' interests (Smith 2003). It is the contention here that in practice, most directors are seen to be constrained by the theory to run companies for increasing shareholders' profits in short-term. Therefore, when faced with business competition, they are always under enormous pressure to look for short-term benefits as a safety measure to either increase shareholders' wealth or avoid a takeover or avoid being removed.

\section{2) Moral and Ethical Issues}

It has also been argued that the shareholder primacy theory lacks moral and ethical values (Pedamon 2002). The contention here is that directors are made to concentrate only on increasing shareholders' wealth to the detriment and neglect of other stakeholders' interests. Although, the theory does not forbid directors from considering the interests of other stakeholders, it does not affirm the position of these interests either. It is arguable that given the absence of a clearly stated aim to protect the interests of other stakeholders, directors might not mind selling lower quality products to customers and disclaim responsibility to community for the sole purpose of maximizing shareholders wealth. It follows that directors would not have to take any CSR to the other stakeholders as their business is focus on maximizing profits of shareholders at all cost.

\section{3) Corporate Scandals and Financial Crisis}

Also recent development in corporations has been blamed on the shareholder primacy theory. Commentators assert that corporate scandals including Enron, Worldcom and Tyco exposed the inefficiencies of this theory (Freeman, Wicks and Parman). These companies were focused on maximizing the short-term benefits of shareholders, just as the managers were found to be clearly involved in fraudulent activities to promote their personal welfare (Smith 2003). The disadvantages of the shareholder value principle, particularly the pursuit of immediate short-term interests and a lack of responsibility to stakeholders (primarily customers) have been suggested as the main reasons for the 2008 global financial crisis. Nevertheless, advocates still hold the view that when viewed from a long-term perspective, the shareholder primacy theory provides the best framework in balancing the competing interests of various stakeholders when making business decisions.

\subsection{Argument for Shareholder Primacy Theory}

\section{1) Efficiency}

It has been claimed from the viewpoint of economic efficiency that the shareholder primacy theory boosts both the shareholders' interests and increases societal wealth (Smith 2003). According to Adam Smith, "the pursuit of profit ultimately promotes social welfare through the "invisible hand" (Ibid). For in- 
stance, in order to enhance profits, companies would necessarily need to produce good quality products and services to customers otherwise they would be forced to close down shortly. The effect of closing down will be no returns in terms of dividends to shareholders. It follows that companies and their directors would need to think on how to survive and attract customers for the purpose of making profits. The effect will be enhanced quality of goods and services, which will in turn build a higher standard of economic structure to the benefit of the whole society.

Furthermore, directors are said to be able to work more effectively as they have a single goal which is profit maximization. The argument is that, there are numerous groups of people with divergent interests involved in corporations, if the duties of directors were to be owed to a multitude, all conflicting interests would not be balanced and it would be impossible for directors to handle. The effect would be poor decision making and the exacerbation of opportunism to the benefit of directors. This it is argued is resolved by shareholder primacy theory as the directors are required to concentrate on one goal, profit maximization.

It has been contended however, that efficiency is a variable and cannot hold the same effect under different CG systems. Other features such as fairness in running business have to be considered, as efficiency is not the sole standard of good business practice. Despite these misgivings against the efficiency of shareholder primacy, it does appear a better argument for shareholder primacy. For in maximizing shareholders' profits, the interests of other stakeholders are fostered as well. This no doubt enhances social wealth for the good of all stakeholders.

\section{2) The Agency Claim}

According to this claim, shareholders employ directors as their agents to manage the daily business of companies. As the principal, shareholders legally lead and direct the directors on how to perform their duties, and ensure that the directors are accountable to the shareholders. This therefore, moderate directors' misconduct and prevent resort to self-interests. However, this claim cannot hold water as the agency relationship between shareholders and directors does not exist. Now directors are for instance employed by companies and not shareholders.

Although, the directors are elected by the shareholders, the parties to the employment contract are the companies and the directors. It follows that the directors owe their duties to the company. Besides, directors are not agents of shareholders, as they cannot sign a contract with third parties to transfer shareholders' shares unless specially empowered to do so. Also, the management of companies is the responsibility of the board of directors, thus directors are exclusively and independently engaged for the running of companies business and the shareholders have no direct control right over directors. It follows that the agency theory has failed to support the theory of shareholder primacy.

It remain to be said that despite the benefits of the shareholder primacy theory, such as promoting economic efficiency, it is becoming unpopular. The 
theory ignores other stakeholders' contribution to the success of the company, lacks moral and ethical values, eschews CSR and encourages shareholders opportunism.

\subsection{The Stakeholder Theory}

A side of the discussion is the stakeholder theory, which asserts that besides making a profit and obeying the law, a corporation would try to mitigate or solve the social problems (Jones \& Wicks 1999). Advocates of this theory hold the view that the directors owe a duty to both the shareholders and "individuals and constituencies that contribute, either voluntarily or involuntarily, to [a corporation's] wealth-creating capacity and activities, and who are therefore its potential beneficiaries and/or risk bearers'” (Post, Preston, \& Sachs 2002).

Although, there is some debate regarding that stakeholders deserve consideration, a widely accepted interpretation maintains that corporations should consider the effects of their actions upon the shareholders, customers, suppliers, general public, employees, and others with a stake or interest in the corporation (Evan \& Freeman 1988). Advocates of this theory reason, that by providing for stakeholders needs, the corporation ensures its continued success. It follows that the that the goal is to align income maximisation with the corporation's long-term success in order to remain a going concern. Furthermore, the stakeholder theory posits that, increased CSR makes corporations more attractive to consumers, as such, CSR should be undertaken by all corporations. The theory further asserts that the interests of all stakeholders be considered even if it reduces company profitability (Donaldson \& Dunfee 1999). Guthrie and Parker hold the view that by providing for the desires of stakeholders, the corporation legitimizes its continue existence (Guthrie \& Parker 1989). This is because society provides important benefits to the corporation, hence the corporation is obligated to promote society's interest in return (Ibid).

Like the shareholder primacy theory, the stakeholder theory also suffers from some criticisms. We shall briefly address these misgivings.

\section{1) Overregulation.}

It is argued that the potential for overregulation strikes a formidable blow to stakeholder theory. The contention is that the pursuit of CSR would lead to more rigorous regulations for business. For instance, mandating CSR reporting would render CSR meaningless. This view was endorsed by the Australian Parliamentary Joint Committee on Corporations and Financial Services in June 2006 in its report: Corporate Responsibility: Managing Risk and Creating Value. The key conclusion of the report stated:

The committee strongly supports further successful engagement in the voluntary development and wide adoption of corporate responsibility. The committee has formed the view that mandatory approaches to regulating director's duties and to sustainability reporting are not appropriate. Consequent on the recommendations of this report, the committee expects in- 
creasing engagement by corporations in corporate responsibility activities.

This would obviate any future moves towards a mandatory approach

Although increased CG regulation by various regulatory bodies in recent times has helped in encouraging more companies to adopt CSR principles, it is the writers' view that CSR be a voluntary social effort that go beyond legal obligations. Corporations should not be mandated by regulations to adopt CSR but instead, regulations should only serve to encourage, guide and provide the framework for corporations in adopting CSR objectives voluntarily.

\section{2) Competing Interests of Stakeholders}

Another misgiving of the stakeholder theory is the issue of competing interests of stakeholders. Marcoux expressed this view when he said 'as most everyone recognizes, the interests of shareholders, customers, suppliers, employees, and communities in managing a firm's assets are conflicting' (Marcoux 2003). For instance, shareholders would want the highest possible returns through capital gains and/or dividends. Employees would crave for higher wages and good working condition. The customers would desire high quality products, low prices and excellent service. As Jensen observed, competing demands from stakeholders make the theory untenable, as it would be difficult to balance these interests in practice (Jensen 2002). Some stakeholders would be satisfied while others would be left unhappy. It is further argued that carrying out of CSR would likely cause significant disagreement among stakeholders. For instance, some shareholders might be willing to promote CSR, while others might want the sole pursuit of profit. It follows also that, even when shareholders agree to promote CSR and concede that CSR were beneficial, they may still differ as to where it should be directed.

\section{3) Lack of Profit Motive}

It is also claimed that the stakeholder theory does not demand that a corporation focuses on profitability. On the other hand, this writers share the view that, even though the theory's ultimate objective is the concern for continued existence of the company, this can only be achieved by balancing the interests of all stakeholders, including the shareholders, whose interest are usually addressed through profits. It follows that this claim would not hold water, as the stakeholder theory attempts to balance all stakeholders' interests, profit making inclusive.

\section{Conclusion}

CG is a vital issue where a corporate organization is concerned and cannot be overlooked or played down upon. This is because good CG is in the interest of the organization's smooth running and profitability in the long run. The stakeholders who are external to the corporation form an important aspect knowing they exert considerable influence to the corporation. However, the corporation should determine its primary stakeholders (according to their power level and influence, they exert on the organization) so as to prioritize its level of attention 
on those ones of strategic importance to the organization. It is important that the organization realizes that it is impossible to satisfy all stakeholders hence it is best to create a balance between meeting organizational objectives and that of its stakeholders.

\section{Conflicts of Interest}

The authors declare no conflicts of interest regarding the publication of this paper.

\section{References}

Abdullah, H., \& Valentine, B. (2009). Fundamental and Ethics Theories of Corporate Governance. Middle Eastern Finance and Economics, No. 4, 88-96.

Aguilera, R., \& Gregory, J. (2003). The Cross-National Diversity of Corporate Governance: Dimensions and Determinants. Academy of Management Review, 28, 447-465. https://doi.org/10.5465/amr.2003.10196772

Berle, A. A., \& Means, G. C. (1932). The Modern Corporation and Private Property. New York: Macmillan.

Blair, M.M. (1995). Ownership and Control: Rethinking Corporate Governance for the Twenty-First Century. Washington DC: The Brookings Institution.

Carroll, A. B. (1979). A Three Dimensional Conceptual Model of Corporate Performance. Academy of Management Review, 4, 497-498.

https://doi.org/10.5465/amr.1979.4498296

Code of Corporate Governance for Banks and Discount Houses in Nigeria, and Guidelines for Whistle Blowing in the Nigerian Banking Industry (2019).

http://www.ecgi.org/codes/code.php?code $\mathrm{id}=416$

Code of Corporate Governance for Public Companies in Nigeria (2019).

http://www.sec.gov.ng/code-of-corporate-governance-.html

Coffee, J. C. (1998). Inventing a Corporate Monitor For Transitional Economies: The Uncertain Lessons From the Czech and Polish Experiences. In K. J. Hopt et al (Eds.), Comparative Corporate Governance: The State of the Art and Emerging Research (pp. 67-138). New York: Oxford University Press.

Collier, J., \& Robberts, J. (2001). An Ethic for Corporate Governance? Business Ethics Quarterly, 11, 67-71. https://doi.org/10.5840/beq20011117

Davies, P. L., \& Worthington, S. (2012). Gower and Davies Principles of Modern Company Law (pp. 502-560). London: Maxwell.

Donaldson, T., \& Dunfee, TW. (1999). Ties that Bind: A Social Contracts Approach to Business Ethics (Chapter 9). Boston, MA: Harvard Business School Press..

Donaldson, T., \& Preston, L. E. (1995). The Stakeholder Theory: Concepts, Evidence and Implications. Academy of Management Review, 20, 65-91.

https://doi.org/10.5465/amr.1995.9503271992

Emmons, W. R., \& Schmid, F. A. (1999). Corporate Governance and Performance. Working Paper 1999-018A. Federal Reserve Bank of St. Louis. https://doi.org/10.20955/wp.1999.018

Evan, W. M., \& Freeman, R. E. (1988). A Stakeholder Theory of the Modern Corporation: Kantian Capitalism. In T. L. Beauchamp, \& N. E. Bowie (Eds.), Ethical Theory and Business (3rd ed., pp. 97-106). Upper Saddle River, NJ: Prentice-Hall. 
Ferrell, C. O., Fraedrich, J., \& Ferrell, L. (2005). Business Ethics: Ethical Decision Making and Cases (6th ed., pp. 67). Boston, MA: Houghton Mifflin Company.

Freeman, R. E. (1994). Strategic Management: A Stakeholder Approach. Boston: Pitman. The Politics of Stakeholder Theory: Some Future Directions. Business Ethics Quarterly, 4, 409-421. https://doi.org/10.2307/3857340

Freeman, R. E. (2008). Managing for Stakeholders. In J. Azekhem, E. D. Palmer, \& L. M. Stoll (Eds.), Stakeholder Theory (pp. 1-27). New York: Prometheus Books; In C. Ljubojevic, \& G. Ljubojevic (Eds.), Improving the Stakeholder Satisfaction by Corporate Governance Quality (pp. 22-35). Skola Biznisa.

Freeman, R. E., Wicks, A. C., \& Parmar, B. (2004). Stakeholder Theory and the Corporate Objective Revisited. Organization Science, 15, 364-369.

https://doi.org/10.1287/orsc. 1040.0066

Friedman, M. (1962). Capitalism and Freedom (pp. 133). Chicago, IL: University of Chicago Press.

Friedman, M. (2002). The Social Responsibility of Business Is to Increase Its Profits. In L. P. Hartman (Ed.), Perspectives in Business Ethics (2nd ed., pp. 260-264). New York: McGraw-Hill Companies.

Gelter, M. (2011). Taming or Protecting the Modern Corporation? Shareholder-Stakeholder Debates in a Comparative Light. NYU Journal of Law and Business, 7, 657.

Guthrie, J., \& Parker, L. D. (1989) Corporate Social Reporting: A Rebuttal of Legitimacy Theory. Accounting \& Business Research, 76, 343-348+352.

https://doi.org/10.1080/00014788.1989.9728863

Imala, O. I. (2007). Promoting Good Corporate Governance: The Role of Independent Directors. CBN Bullion, 31, 55.

Jensen, M. C. (2002). Value Maximization, Stakeholder Theory and the Corporate Objective Function. Business Ethnics Quarterly, 12, 235-264. https://doi.org/10.2307/3857812

John, K., \& Senbet, L. (1998). Corporate Governance and Board Effectiveness. Journal of Banking and Finance, 22, 371-403. https://doi.org/10.1016/S0378-4266(98)00005-3

Jones, T. M., \& Wicks, A. C. (1999). Convergent Stakeholder Theory. Academy of Management Review, 24, 206-221. https://doi.org/10.5465/amr.1999.1893929

Kajola S. O. (2008). Corporate Governance and Firm Performance: The Case of Nigerian Listed Firms. European Journal of Economics, Finance and Administrative Sciences, No. 14, 17-28.

Kazmi, E. (2008). Strategic Management and Business Policy(3rd ed., pp. 87). New Delhi: Tata McGraw-Hill.

La Porta, R., Lopez-De-Silanes, F., \& Shleifer, A. (2000). Investor Protection and Corporate Governance. Journal of Financial Economics, 58, 3-27. https://doi.org/10.1016/S0304-405X(00)00065-9

Marcoux, A. M. (2003). A Fiduciary Argument Against Stakeholder Theory. Business Ethics Quarterly, 13, 1-24. https://doi.org/10.5840/beq20031313

McRitchie, J. (2001). Corporate Governance Enhancing the Return on Capital through Increased Accountability. http://www.Amazon.com

Mehar A. (2003). Corporate Governance and Dividend Policy (pp. 1-13). Munich Personal RePEc Archive Paper No. 619.

Monks, R. A. G., \& Minow, N. (2004). Corporate Governance (3rd ed.). Malden, MA: Blackwell. 
Odaki, K., \& Kodama, N. (2010). Stakeholder-Oriented Corporate Governance and Firm-Specific Human Capital: Wages Analysis of Employer-Employee Matched Data (pp. 1-21). Research Institute of Economy, Trade and Industry Paper Series 10-E-014.

Oladimeji, A. (2007). Corporate Governance in Nigeria: An Overview. CBN Bullion, 31, $1-6$.

Oman, C. P. (2001). Corporate Governance and National Development, An Outgrowth of the OECD Development Centres Experts Workshop in 2000 and Informal Policy Dialogue in 2001 Sponsored in Part by CIPE.

Organisation for Economic Co-Operation and Development (OECD, 1999, 2004).

Oso, L., \& Semiu, B. (2012). The Concept and Practice of Corporate Governance in Nigeria: The Need for Public Relations and Effective Corporate Communications. Journal Communications, 3, 1-16. https://doi.org/10.1080/0976691X.2012.11884790

Parliamentary Joint Committee on Corporations and Financial Services (2006). Corporate Responsibility: Managing Risk and Creating Value. Canberra: Commonwealth of Australia. http://outageaph.aph.gov.au/

Pedamon, C. (2002). Corporate Social Responsibility: A New Approach to Promoting Integrity and Responsibility. Company Lawyer, 31, 172-173.

Post, J. E., Preston, L. E., \& Sachs, S. (2002). Managing the Extended Enterprise: The New Stakeholder View. California Management Review, 45, 5-28.

https://doi.org/10.2307/41166151

Romano, R. (1998). Empowering Investors: A Market Approach to Securities Regulation. In K. J. Hopt et al (Eds.), Comparative Corporate Governance: The State of the Art and Emerging Research (pp. 143-217). New York: Oxford University Press.

SEC Website with a Guide of All Corporate Governance Rules and Code in Nigeria. (2019). http://www.sec.gov.ng/rules-and-codes.html

Shleifer, A., \& Vishny, R. W. (1997). A Survey of Corporate Governance. Journal of Finance, 52, 737-783. https://doi.org/10.1111/j.1540-6261.1997.tb04820.x

Smith, H. J. (2003). The Shareholders vs. Stakeholders Debate. MIT Sloan Management Review, 44, 85-90.

Wieland, J. (2005). Corporate Governance, Value Management, and Standards: A European Perspective. Business \& Society, 44, 74-93. https://doi.org/10.1177/0007650305274852

Wogu, O. (2019). Corporate Governance: The Stakeholders Perspective. International Journal of Business and Management Review, 34, 423-433.

Zollinger, P. (2009). Stakeholder Engagement and the Board: Integrating Best Governance Practices, Global Corporate Governance Forum. Focus, 8, 1-6. 